\title{
Efforts to Improve Learning Outcomes in Theme 3 Sub-theme 3 by Using Cooperative Learning Learning Strategies
}

\section{Tri Widiyanti}

SD Swasta Wijayakusuma

triwidiyati1717@gmail.com

\section{Article History}

accepted 14/11/2020

\begin{abstract}
The purpose of this study was to improve student learning outcomes on theme 3 sub-theme 3 in grade III elementary schools with cooperative learning strategies. The research conducted was a Classroom Action Research (CAR) in three cycles, with each cycle consisting of one meeting. The stages of each cycle are planning, implementing, observing and reflecting. Each meeting is conducted with a formative test to determine the development of students. In the first cycle students who completed after carrying out the formative test were $53.1 \%$. In cycle II students who completed after carrying out the formative test were $81.25 \%$. In the third cycle students who completed after carrying out the formative test were $87.5 \%$. These results indicate that the cooperative learning strategy can improve student learning outcomes, especially the subject matter of the theme 3 sub-themes 3 Class III at Wijayakusuma Private Elementary School.
\end{abstract}

Keywords: learning outcomes, cooperative learning, theme 3, sub-theme 3

\begin{abstract}
Abstrak
Tujuan dari penelitian ini adalah untuk meningkatkan hasil belajar peserta didik pada tema 3 subtema 3 di sekolah dasar kelas III dengan strategi pembelajaran cooperative learning. Penelitian yang dilakukan adalah Penelitian Tindakan Kelas (PTK) sebanyak tiga siklus, dengan setiap siklusnya terdiri dari satu pertemuan. Tahapan setiap siklusnya adalah perencanaan, pelaksanaan, pengamatan dan refleksi. Setiap pertemuan dilakukan tes formatif untuk mengetahui perkembangan peserta didik. Pada siklus I peserta didik yang tuntas setelah melaksanakan tes formatif sebesar 53,1\%. Pada siklus II peserta didik yang tuntas setelah melaksanakan tes formatif sebesar $81,25 \%$. Pada siklus III peserta didik yang tuntas setelah melaksanakan tes formatif sebesar $87,5 \%$. Hasil ini menunjukan bahwa strategi pembelajaran cooperative learning dapat meningkatkan hasil belajar peserta didik khususnya materi tema 3 subtema 3 Kelas III di SD Swasta Wijayakusuma.
\end{abstract}

Kata kunci: hasil belajar, cooperative learning, tema 3,subtema 3

Social, Humanities, and Education Studies (SHEs): Conference Series https://jurnal.uns.ac.id/shes
p-ISSN 2620-9284

e-ISSN 2620-9292 


\section{PENDAHULUAN}

Pembelajaran adalah proses interaksi peserta didik dengan pendidik dan sumber belajar pada suatu lingkungan belajar (UUSPN NO. 20 Tahun 2003 pasal 1 ayat 10). Definisi ini menjadi landasan yuridis formal tentang teknis pelaksanaan pembelajaran bahwa pembelajaran harus dilakukan secara interaktif,hal ini dapat dipahami karena secara psikologis setiap individu terlahir sebagai manusia yang aktif dalam belajar, oleh karena itu pembelajaran harus dibangun di atas paradigma student centered dan meminimalisir peran teacher centered yang akhirnya memfasilitasi siswa belajar.

Pada kurikulum 2013 sekolah dasar di Indonesia sudah disajikan dalam pembelajaran tematik, termasuk di SD Wijayakusuma Kecamatan Lasem Kabupaten Rembang. Hasil dari observasi guru menyatakan bahwa dengan adanya pembelajaran tematik siswa terlihat jelas karakter dan bakatnya lebih muncul, namun siswa kurang fokus dalam materi. Maka dari itu peneliti ingin membangun siswa untuk fokus dalam menerima materi, agar siswa mendapatkan hasil belajar yang baik. Peneliti mengambil penelitian pada materi Tema 3 Subtema 3 untuk pembahasan dalam penelitian disekolah tersebut. Hasil belajar adalah kemampuan-kemampuan yang dimiliki siswa setelah ia menerima pengalaman belajarnya

Pada faktanya salah satu dari siswa di kelas III di SD Wijayakusuma Lasem, dengan hasil observasi bahwa hasil belajar siswa di kelas III belum memuaskan karena nilai hasil belajar siswa belum mencapai nilai KKM 75, Dari jumlah siswa sebanyak 32 orang, yang mendapat nilai di atas 75 sebesar 13 siswa (41\%) dan yang lainnya sejumlah 19 siswa (59 \%) mendapat nilai di bawah KKM.

Menurut Bloom dalam Sudjana (2001:22) membagi hasil belajar menjadi tiga ranah, yaitu: 1) Ranah kognitif, berkenaan dengan hasil belajar intelektual yang terdiri dari pengetahuan atau ingatan, pemahaman, aplikasi, analisis, sintesis dan evaluasi, 2) Ranah afektif, berkenaan dengan sikap yang terdiri dari penerimaan jawaban atau reaksi, penilaian, 3) Ranah psikomotorik, berkenaan dengan hasil belajar keterampilan dan kemampuan bertindak. Hasil belajar adalah suatu hasil yang telah dicapai setelah mengalami proses belajar mengajar atau setelah mengalami interaksi dengan lingkungannya guna memperoleh ilmu pengetahuan dan akan menimbulkan perubahan tingkah laku yang relatif menetap dan tahan lama.

Strategi pembelajaran Cooperative Learning yaitu strategi pembelajaran yang menitikberatkan pada pengelompokan siswa dengan tingkat kemampuan akademik yang berbeda kedalam kelompok-kelompok kecil (Saptono, 2003:32). Siswa diajarkan keterampilan-keterampilan khusus agar dapat bekerja sama dengan baik dalam kelompoknya, seperti menjelaskan kepada teman sekelompoknya, menghargai pendapat teman, berdiskusi dengan teratur, siswa yang pandai membantu yang lebih lemah, dan sebagainya. Pembelajaran kooperatif adalah salah satu bentuk pembelajaran yang berdasarkan faham konstruktivisme.Pembelajaran kooperatif merupakan strategi belajar dengan sejumlah siswa sebagai anggota kelompok kecil yang tingkat kemampuannya berbeda. Dalam penyelesaian tugas kelompoknya, setiap siswa harus saling bekerja sama, saling membantu untuk memahami materi pelajaran. Dalam belajar dikatakan belum selesai jika salah satu anggota belum menguasai bahan pelajaran (Isjoni, 2011:14). Menurut Anita Lie dalam bukunya "Cooperative Learning", bahwa model pembelajaran kooperatif tidak sama dengan sekedar belajar kelompok, tetapi ada unsur-unsur dasar yang membedakannya dengan pembagian kelompok yang dilakukan asal-asalan. Jadi, strategi pembelajaran cooperatif learning dapat diartikan sebagai sebuah proses pembelajaran dimana siswa dibagi dalam kelompok-kelompok kecil, lalu masing-masing anggota kelompok bekerjasama dan saling membantu satu sama lain. 


\section{METODE}

Penelitian ini adalah penelitian tindakan kelas (Classroom Action Research) dengan menerapkan strategi pembelajaran cooperative learning. Adapun langkahlangkah PTK yang akan dilaksanakan mengacu pada model Kemmis dan Mc Taggart, setiap siklus atau putaran terdiri empat tahapan yaitu perencanaan (planning), aksi atau tindakan (acting), pengamatan (observing), dan refleksi (reflecting). Analisis penelitian ini adalah analisis deskriptif kuantitafif kualitatif dimana dalam penelitian ini selain penyajian hasil berupa data maupun angka peneliti juga menentukan bagaimana cara pengolahan hasil penelitian yakni dengan membuat analisisnya dengan menerapkan strategi cooperative learning. Penelitian ini dilaksanakan pada peserta didik kelas III SD Swasta Wijayakusuma Tahun Pelajaran 2020/2021 selama tiga siklus secara daring menggunakan aplikasi Google meet dengan satu pertemuan disetiap siklusnya. Siklus I dilaksanakan pada tanggal 2 November 2020. Siklus II dilaksanakan pada tanggal 7 November 2020. Siklus III dilaksanakan pada tanggal 20 November 2020. Teknik pengumpulan data yang dilakukan dengan observasi dan test formatif. Observasi meliputi observasi keterlaksanaan strategi cooperative learning, sikap peserta didik dan keterampilan. Untuk hasil belajar menggunakan tes formatif melalui Google form.

\section{HASIL DAN PEMBAHASAN}

Hasil yang diperoleh dalam pelaksanaan perbaikan pembelajaran dalam penelitian tindakan kelas ( PTK) di SD Wijayakusuma Lasem dalam Materi Tema 3 Subtema 3 di kelas III yang dilaksanakan dalam 3 siklus.

Pada perbaikan pembelajaran siklus 1 dengan memfokuskan strategi cooperative learning. Pada siklus I pembelajaran dilaksanakan selama satu pertemuan, setiap pertemuan diadakan tes formatif. Untuk mengetahui perkembangan peserta didik selama pembelajaran. Berikut ini adalah hasil belajar peserta didik pada siklus I yang bisa dilihat pada tabel berikut.

Tabel 1. Hasil Belajar Peserta Didik Siklus I

\begin{tabular}{llc}
\hline No & \multicolumn{1}{c}{ Indikator } & Keterangan \\
\hline & & \\
1 & Jumlah siswa & 32 \\
2 & Kriteria Ketuntasan Minimum & 75 \\
3 & Nilai Terendah & 68 \\
4 & Nilai Tertinggi & 96 \\
5 & Jumlah Nilai & 2568 \\
6 & Rata-rata Nilai & 80,25 \\
7 & Banyak siswa yang mendapat nilai 75 keatas & 17 \\
8 & Prosentase siswa yang mendapat nilai 75 keatas & $53,1 \%$ \\
9 & Banyak siswa yang mendapat nilai kurang dari 75 & 15 \\
10 & Prosentase siswa yang mendapat nilai kurang dari 75 & $46,9 \%$ \\
& & \\
\hline
\end{tabular}

Dari tabel diatas terlihat bahwa ada 17 siswa yang mendapatkan nilai 75 keatas atau sebesar $53,1 \%$ dan 15 siswa atau $46,9 \%$ memperoleh nilai kurang dari 75 . Nilai terendah berada di nilai 68 dan nilai tertinggi mengalami peningkatan yaitu 96, hasil belajar siswa pada siklus I mengalami kenaikan yang signifikan. Keberhasilan pembelajaran siklus I ini sebesar $53,1 \%$ siswa tuntas dan $46,9 \%$ siswa belum tuntas. Pada perbaikan proses pembelajaran siklus I berjalan dengan lancar sesuai dengan tujuan pembelajaran. Baik guru dan siswa terlibat dalam proses pembelajaran yang menggunakan strategi cooperative learning walaupun belum sempurna. Beberapa siswa masih ragu-ragu untuk menjawab pertanyaan dari guru. Tetapi pada perbaikan pembelajaran siklus I yang menggunakan strategi cooperatif learning siswa dibagi 
dalam kelompok. Tetapi kelompok yang diharapkan belum berjalan dengan efektif dikarenakan pembelajaran daring, sehingga pembelajaran kurang efektif.

Berdasarkan refleksi pada siklus I maka peneliti memutuskan untuk melanjutkan ke siklus II dikarenakan belum mencapai ketuntasan klasikal yang diharapkan. Pada perbaikan pembelajaran siklus II dengan memfokuskan strategi cooperative learning. Pada siklus II pembelajaran dilaksanakan selama satu pertemuan, setiap pertemuan diadakan tes formatif. Untuk mengetahui perkembangan peserta didik selama pembelajaran. Berikut ini adalah hasil belajar peserta didik pada siklus II yang bisa dilihat pada tabel berikut.

Tabel 2. Hasil Belajar Peserta Didik Siklus II

\begin{tabular}{llc}
\hline No & \multicolumn{1}{c}{ Indikator } & Keterangan \\
\hline & & \\
1 & Jumlah Siswa & 32 \\
2 & Kriteria Ketuntasan Minimum & 75 \\
3 & Nilai Terendah & 47 \\
4 & Nilai Tertinggi & 100 \\
5 & Jumlah Nilai & 2694 \\
6 & Rata-rata Nilai & 84,2 \\
7 & Banyak siswa yang mendapat nilai 75 keatas & 26 \\
8 & Prosentase siswa yang mendapat nilai 75 keatas & $81,25 \%$ \\
9 & Banyak siswa yang mendapat nilai kurang dari 75 & 6 \\
10 & Prosentase siswa yang mendapat nilai kurang dari 75 & $18,75 \%$ \\
& & \\
\hline
\end{tabular}

Berdasarkan tabel diatas, ternyata pada perbaikan pembelajaran siklus II sebagian besar siswa memperoleh nilai baik. Terbukti dari rata-rata kelas yang meningkat menjadi 84,2 dari 32 siswa, 26 siswa mendapat nilai 75 ke atas dengan presentase $81,25 \%$ dan 6 siswa mendapat nilai kurang dari 75 dengan presentase $18,75 \%$. Pada proses pembelajaran sudah berjalan dengan lancar sesuai dengan tujuan pembelajaran. Penerapan strategi cooperative learning membuat siswa terlibat aktif dalam proses pembelajaran. Siswa yang sebelumnya kurang berani menjawab pertanyaan, pada siklus II ini mereka sudah berani menjawab dan tampil didepan kelas karena guru memberikan reward untuk meningkatkan motivasi siswa. Pembentukan kelompok belajar yang heterogen memudahkan siswa dalam berdiskusi. Secara keseluruhan siswa sudah tertarik dan termotivasi dengan digunakannya strategi cooperatif learning dalam pengajaran Tema 3 Subtema 3. Kurang maksimalnya hasil belajar siswa pada pembelajaran siklus II.Oleh karena itu peneliti memutuskan untuk mengadakan perbaikan pembelajaran siklus III.

Pada perbaikan pembelajaran siklus III dengan memfokuskan strategi pembelajaran cooperative learning dilaksanakan selama satu pertemuan dan tiap pertemuan diadakan tes formatif untuk mengetahui perkembangan peserta didik selama pembelajaran. Berikut ini adalah hasil belajar peserta didik pada siklus III yang bisa dilihat pada tabel berikut. 
Tabel 3. Hasil Belajar Peserta Didik Siklus III

\begin{tabular}{llc}
\hline No & \multicolumn{1}{c}{ Indikator } & Keterangan \\
\hline & Jumlah Siswa & 32 \\
2 & Kriteria Ketuntasan Minimum & 75 \\
3 & Nilai Terendah & 50 \\
4 & Nilai Tertinggi & 100 \\
5 & Jumlah Nilai & 2780 \\
6 & Rata-rata Nilai & 86,9 \\
7 & Banyak siswa yang mendapat nilai 75 keatas & 28 \\
8 & Prosentase siswa yang mendapat nilai 75 keatas & $87,5 \%$ \\
9 & Banyak siswa yang mendapat nilai kurang dari 75 & 4 \\
10 & Prosentase siswa yang mendapat nilai kurang dari 75 & $12,5 \%$ \\
& & \\
\hline
\end{tabular}

Berdasarkan table di atas dari 32 siswa nilai rata- rata yang diperoleh yaitu 86,9 . Banyak siswa yang mendapat nilai 75 ke atas sebanyak 28 siswa dengan presentase $87,5 \%$ dan siswa yang mendapat nilai kurang dari 75 sebanyak 4 siswa dengan presentase $12,5 \%$. Berdasarkan pengamatan siklus III dilaksanakan, perubahan yang diharapkan sudah tercapai. Dari segi pembelajaran sudah berjalan dengan lancar dan kondusif, guru sebagai fasilitator menjalankan tugasnya dengan efisien.Berdasarkan pengamatan tingkah laku siswa pada siklus III ini telah mengalami perubahan yang sesuai harapan. Siswa tidak lagi merasa kesulitan dalam menerima materi,siswa tidak merasa takut dan malu ketika melaporkan hasil pengamatannya, bahkan beberapa siswa menunjukkan kemampuan yang lebih dibandingkan temantemannya. Tetapi justru hal ini menjadi semangat bagi siswa yang lain untuk melakukan hal yang sama.

\section{SIMPULAN}

Melalui penerapan strategi cooperative learning dapat meningkatan hasil belajar siswa dalam materi Tema 3 Subtema 3 bagi siswa Kelas III SD Wijayakusuma Kecamatan Lasem Kabupaten Rembang tahun Pelajaran 2020/2021, yang ditunjukkan dengan peningkatan rata- rata kelas pada siklus I mencapai 80,25 ,pada siklus II mencapai 84,2, dan pada siklus III mencapai 86,9. Sedangkan siswa yang tuntas pada perbaikan siklus I sebanyak 17 siswa (53,1\%), pada perbaikan siklus II sebanyak 26 siswa $(81,25 \%)$, dan pada siklus III sebanyak 28 siswa ( $87,5 \%)$. Dalam melaksanakan pembelajaran Tema 3 Subtema 3, strategi cooperative learning hendaknya digunakan oleh guru khususnya pada pembelajaran. Karena kegiatan pembelajaran ini terbukti meningkatkan hasil belajar siswa. Pembelajaran hendaknya bermakna bagi siswa sehingga siswa tertarik dengan materi yang diajarkan.Pola mengajar menggunakan metode ceramah harusnya diminimalisir. Karena penggunaan metode tersebut membuat siswa pasif dan terbiasa menerima begitu saja sehingga pembelajaran menjadi tidak bermakna.

\section{DAFTAR PUSTAKA}

Isjoni. (2011). Pembelajaran Kooperatif: Meningkatkan Kecerdasan Komunikasi antar Peserta Didik. Yogyakarta: Pustaka Pelajar

Kemmis dan Teggart. 1998. The Action Research Planer. Deaken Univercity Lie, Anita. (2005). Cooperative learning. Jakarta: Grasindo

Saptono. (2003). Strategi Belajar Mengajar Biologi (UNNES : Semarang)

Sudjana, N. (2009). Penilaian Hasil Proses Belajar Mengajar (Cetakan Ketigabelas). Bandung: PT Remaja Rosdakarya 